\title{
Analysis of the Effect of Information Technology and Organizational Culture Through Motivation on Lecturer Performance Quality
}

\author{
Ulfah Mediaty Arief ${ }^{1}$, Haryono $^{2}$, Dwi Yuwono Puji Sugiharto ${ }^{3}$, and Achmad Rifai ${ }^{4}$ \\ Graduate School Program, UniversitasNegeri Semarang, Indonesia \\ \{ulfahmediatyarief@mail.unnes.ac.id\}
}

\begin{abstract}
Keywords: Information Technology, Lecturer Performance, Motivation, Organizational Culture.
Abstract: Lecturer performance can be influenced by several things such as the ability to use information technology, organizational culture, and self-motivation. This study aims to determine the effect of information technology, organizational culture on lecturer performance through motivation. The survey method was used in collecting data on 150 lecturers who were randomly selected as research samples. The questionnaire results data are then processed with Structural Equation Modelling (SEM) using WarpPLS 6.0. The results of this study indicate that motivation directly has a significant effect on lecturer performance. Information technology and organizational culture indirectly through motivation have a significant influence on lecturer performance.
\end{abstract}

\section{INTRODUCTION}

Higher Education is a place for educational providers that aim to produce quality human resources and be able to face increasingly fierce work competition (Yahya Hidayati, 2014).Ramli and Jalinus revealed that lecturer performance needs to be maintained considering lecturers are an important component of the quality of higher education so that they are able to produce graduates with good quality. The performance of lecturers as instructors influences the quality of the process and results of higher education Kusumajati, 2017; Amang, 2011; Angrist, 2014). Therefore, lecturer development and performance measurement are very important (Indrajit, 2007).

Performance is the result of work or activities obtained during a certain period (Mangkunegara, 2009). The quality and commitment of lecturers is the main key to the success of higher education institutions (Amang, 2011; Angrist, 2014). The performance of the lecturer must be guided by the tri dharma of higher education covering the principles of education, research, and community service. One form of lecturer work indicator is seen from scientific publications carried out, both from research and service. The scientific publications of Indonesian lecturers are still estimated to be 5,125 publications, under Malaysia which have reached 5,999 publications. Even though the number of publications is number two in ASEAN, the level of citation is decreasing (Seftiawan,2018).

The factors that influence the achievement of performance are the ability factor (ability) and motivation factor (motivation) (Mangkunegara, 2009).Wigfield (2014) stated that the motivation is an impulse in a person to be able to do something to achieve certain goals to the fullest.Work motivation is also one of the factors that influence lecturer performance(Broni, 2012; Samuel et al, 2015). Motivation has a significant positive effect on company performance(Ayu and Suprayetno, 2008). At the college level, work motivation also has a positive and significant effect on the quality of the performance of lecturers (Riyadi et al, 2017; Sulastri, 2007).Samuel et al (2015) Revealed that there is a correlation between motivation and lecturer performance based on research at Ghanaian Polytechnics, where motivation contributes to a variation of $79.5 \%$ and can predict performance significantly. Motivation is beneficial and leads to initiation and innovation based on research with the object of Staff at the University of Ghana (Broni, 2012). Research in 2018, on staff at Alvan Ikoku's Federal College of Education (AIFCE) shows that work motivation can affect work performance (Olusadum and Anulika, 2018).

Factors that can affect one's motivation include culture in an organization. Organizational culture is the values that are accepted by all members of the organization as 
Semarang. The performance evaluation of lecturers in this research refers to the lecturer workload of UniversitasNegeri Semarang. Next in part II will discuss the methods, then Part III discusses the analysis process, results, and discussion. While the conclusions are in section IV.

\section{METHODS}

This research was conducted using a quantitative approach to the process of collecting data using survey methods. The instrument used in data collection was a questionnaire that had a total of 30 indicators divided into 5 variables, that are information technology which had 6 indicators, organizational culture with 11 indicators, motivation with 7 indicators, and lecturer performance with 6 indicators. The study population was lecturers at Semarang State University where 150 lecturers were randomly selected as samples. Analysis using Structural Equation Model (SEM) supported by WarpPLS 6.0 software. Data analysis was performed by looking at the results of convergent validity, discriminant validity, and composite reliability to determine the effect of latent variables with their constituent indicators. Path coefficients are used to see the direct and indirect relationship between information technology and organizational culture through motivation as to lecturer performance.

\section{RESULTS AND DISCUSSIONS}

Based on the results of the questionnaire results to 150 lecturers containing 30 forming indicators of the 4 variables studied the following results were obtained.

\subsection{Convergent Validity}

This evaluation is done by taking into account the outer loading value of each variable in this study, and if the value shows is greater than 0.50 then the item is declared valid. The calculation results presented below are derived from the results of the WarpPLS output: 
Table 1. Loading factor each item

\begin{tabular}{|c|c|c|c|c|c|c|c|c|c|}
\hline Variables & $\overline{\text { Items }}$ & Loading & $\mathrm{T}$ value & $P$ value & Variables & Items & Loading & $\mathrm{T}$ value & $P$ value \\
\hline \multirow{6}{*}{ LP } & LP.1 & 0.569 & 7.904 & $<0.001$ & \multirow{8}{*}{$\mathrm{OC}$} & OC.4 & 0.723 & 10.392 & $<0.001$ \\
\hline & LP. 2 & 0.515 & 7.069 & $<0.001$ & & OC. 5 & 0.506 & 6.936 & $<0.001$ \\
\hline & LP.3 & 0.631 & 8.893 & $<0.001$ & & OC.6 & 0.665 & 9.439 & $<0.001$ \\
\hline & LP.4 & 0.764 & 11.081 & $<0.001$ & & OC.7 & 0.558 & 7.739 & $<0.001$ \\
\hline & LP.5 & 0.671 & 9.535 & $<0.001$ & & OC. 8 & 0.519 & 7.132 & $<0.001$ \\
\hline & LP. 6 & 0.725 & 10.432 & $<0.001$ & & OC. 9 & 0.658 & 9.321 & $<0.001$ \\
\hline \multirow{6}{*}{ IT } & IT.1 & 0.608 & 8.525 & $<0.001$ & & OC. 10 & 0.761 & 11.043 & $<0.001$ \\
\hline & IT. 2 & 0.832 & 12.253 & $<0.001$ & & OC.11 & 0.728 & 10.483 & $<0.001$ \\
\hline & IT. 3 & 0.737 & 10.627 & $<0.001$ & \multirow{7}{*}{ M } & M.1 & 0.658 & 9.322 & $<0.001$ \\
\hline & IT. 4 & 0.715 & 10.266 & $<0.001$ & & M.2 & 0.684 & 9.753 & $<0.001$ \\
\hline & IT. 5 & 0.637 & 8.981 & $<0.001$ & & M.3 & 0.512 & 7.024 & $<0.001$ \\
\hline & IT.6 & 0.613 & 8.605 & $<0.001$ & & M.4 & 0.700 & 10.014 & $<0.001$ \\
\hline \multirow{3}{*}{$\mathrm{OC}$} & OC. 1 & 0.569 & 7.909 & $<0.001$ & & M.5 & 0.575 & 8.008 & $<0.001$ \\
\hline & OC. 2 & 0.689 & 9.825 & $<0.001$ & & M.6 & 0.744 & 10.744 & $<0.001$ \\
\hline & OC. 3 & 0.732 & 10.540 & $<0.001$ & & M.7 & 0.700 & 10.010 & $<0.001$ \\
\hline
\end{tabular}

The table 1 explains that the overall loading factor value of the variables in this study is greater than 0.5 , the $\mathrm{T}$-Value is greater than 1.97 and the P-Value is less than 0.05 so that the items on these variables has been able to be formed or explained well by the items or can be said to be valid in a convergent manner.

\subsection{Discriminant Validity}

This evaluation is done by using a cross loading value and the value of average variance extracted (AVE) discriminant validity from the measurement model that is assessed based on the measurement of cross loading with variables. If the variable correlation with the measurement principal for each item is greater than the other variables, the latent variable is able to predict items better than other variables.

Cross Loading. This value is another measure of discriminant validity. The expected value that each indicator has a higher loading for the measured construct compared to the loading value to another construct.

Table 2. Cross loading each item

\begin{tabular}{llllllllll}
\hline Items & \multicolumn{1}{c}{ LP } & \multicolumn{1}{c}{ IT } & \multicolumn{1}{c}{ OC } & \multicolumn{1}{c}{ M } & Items & \multicolumn{1}{c}{ LP } & IT & OC & M \\
\hline LP.1 & $\mathbf{0 . 5 6 9}$ & 0.112 & 0.027 & 0.080 & OC.4 & -0.018 & -0.010 & $\mathbf{0 . 7 2 3}$ & -0.105 \\
LP.2 & $\mathbf{0 . 5 1 5}$ & -0.064 & 0.166 & 0.124 & OC.5 & 0.055 & 0.188 & $\mathbf{0 . 5 0 6}$ & 0.046 \\
LP.3 & $\mathbf{0 . 6 3 1}$ & 0.007 & -0.139 & 0.193 & OC.6 & -0.047 & -0.101 & $\mathbf{0 . 6 6 5}$ & -0.162 \\
LP.4 & $\mathbf{0 . 7 6 4}$ & 0.043 & 0.006 & -0.193 & OC.7 & 0.101 & 0.030 & $\mathbf{0 . 5 5 8}$ & 0.210 \\
LP.5 & $\mathbf{0 . 6 7 1}$ & -0.148 & 0.024 & 0.089 & OC. 8 & -0.084 & 0.052 & $\mathbf{0 . 5 1 9}$ & 0.162 \\
LP.6 & $\mathbf{0 . 7 2 5}$ & 0.044 & -0.047 & -0.198 & OC. 9 & -0.111 & -0.011 & $\mathbf{0 . 6 5 8}$ & 0.234 \\
IT.1 & 0.003 & $\mathbf{0 . 6 0 8}$ & -0.044 & -0.005 & OC.10 & -0.074 & -0.238 & $\mathbf{0 . 7 6 1}$ & 0.091 \\
IT.2 & 0.037 & $\mathbf{0 . 8 3 2}$ & 0.023 & -0.122 & OC.11 & 0.026 & -0.200 & $\mathbf{0 . 7 2 8}$ & 0.099 \\
IT.3 & 0.022 & $\mathbf{0 . 7 3 7}$ & -0.030 & -0.171 & M.1 & -0.053 & -0.105 & 0.207 & $\mathbf{0 . 6 5 8}$ \\
IT.4 & 0.009 & $\mathbf{0 . 7 1 5}$ & -0.056 & 0.011 & M.2 & -0.019 & -0.065 & -0.032 & $\mathbf{0 . 6 8 4}$ \\
IT.5 & 0.068 & $\mathbf{0 . 6 3 7}$ & -0.125 & 0.061 & M.3 & 0.046 & -0.030 & 0.121 & $\mathbf{0 . 5 1 2}$ \\
IT.6 & -0.161 & $\mathbf{0 . 6 1 3}$ & 0.243 & 0.299 & M.4 & 0.198 & 0.001 & -0.017 & $\mathbf{0 . 7 0 0}$ \\
OC.1 & 0.158 & 0.110 & $\mathbf{0 . 5 6 9}$ & -0.189 & M.5 & -0.007 & -0.030 & -0.144 & $\mathbf{0 . 5 7 5}$ \\
OC.2 & 0.041 & 0.088 & $\mathbf{0 . 6 8 9}$ & -0.240 & M.6 & 0.037 & 0.050 & -0.130 & $\mathbf{0 . 7 4 4}$ \\
OC.3 & -0.007 & 0.201 & $\mathbf{0 . 7 3 2}$ & -0.086 & M.7 & -0.196 & 0.156 & 0.021 & $\mathbf{0 . 7 0 0}$ \\
\hline
\end{tabular}

Based on the table 2, it can be concluded that each question item is able to be predicted well by each of its latent variables, because the correlation of latent variables is greater than 
other variables so it can be concluded that these variables are discriminatory valid.

Average Variance Extracted. The AVE value is used to measure the amount of variance that can be captured by the construct compared to the variance caused by the measurement error

Table 3. AVE each variable

\begin{tabular}{ccc}
\hline Variable & AVE & Root Square AVE \\
\hline LP & 0.424 & 0.651 \\
\hline IT & 0.483 & 0.695 \\
\hline OC & 0.425 & 0.652 \\
\hline M & 0.432 & 0.658 \\
\hline
\end{tabular}

Table 4. Root square correlation AVE between latent variables

\begin{tabular}{cllll}
\hline Variables & LP & IT & OC & M \\
\hline LP & $\mathbf{0 . 6 5 1}$ & 0.285 & 0.304 & 0.316 \\
\hline IT & 0.285 & $\mathbf{0 . 6 9 5}$ & 0.434 & 0.458 \\
\hline OC & 0.304 & 0.434 & $\mathbf{0 . 6 5 2}$ & 0.539 \\
\hline M & 0.316 & 0.458 & 0.539 & $\mathbf{0 . 6 5 8}$ \\
\hline
\end{tabular}

Based on the table 3 and 4 , the evaluation of the measurement model by comparing the AVE square root with the correlation between variables, it can be concluded that the value of the AVE square root is greater than the correlation between latent variables which means that the results are declared discriminatory valid. The results also show that all AVE root square values are greater than
0.500 which means that discriminant validity is good and the measurement model is also good.

\subsection{Composite Reliability}

This test is carried out by utilizing the value of composite reliability which results can be seen as follows:

Table 5. Composite and Cronbach alpha

\begin{tabular}{ccc}
\hline $\begin{array}{c}\text { Varia } \\
\text { ble }\end{array}$ & Composite Reliability & $\begin{array}{l}\text { Cronbach } \\
\text { Alpha }\end{array}$ \\
\hline LP & 0.813 & 0.724 \\
IT & 0.847 & 0.781 \\
OC & 0.889 & 0.861 \\
M & 0.840 & 0.778 \\
\hline
\end{tabular}

Evaluation of measurements using Composite Reliability and Cronbach Alpha is done to determine whether the high or low reliability of the variable. Measurement values greater than 0.700 indicate that the variable is reliable. Based on the table 5, the results show that the entire value of Composite Reliability and Cronbach Alpha for each variable is greater than 0.700 which means that all variables have high reliability.

\subsection{Path Coefficient}

The test is done by looking at the P-value as a significance level and the betha value as the path coefficient between latent variables

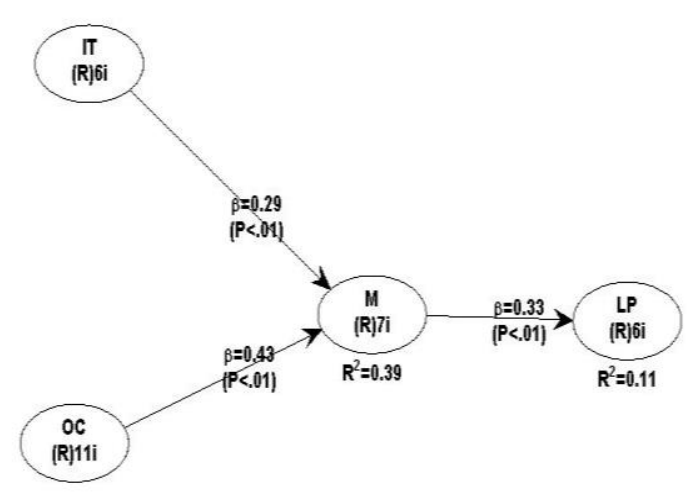

Fig 1. Structural Equation Model 
Amang, B. (2011). Analisis Kinerja Dosen Pada Program Studi. Media Ris. Bisnis Manajemen, 11 (2), 140-173.

\begin{tabular}{ccc}
\hline Path & $\begin{array}{c}\text { Path } \\
\text { Coefficient }\end{array}$ & $\begin{array}{c}\text { P } \\
\text { values }\end{array}$ \\
\hline TI->M & 0.285 & $<0.001$ \\
OC->M & 0.412 & $<0.001$ \\
M->LP & 0.447 & $<0.001$ \\
TI->M->LP & 0.127 & 0.012 \\
OC->M->LP & 0.184 & 0.184 \\
\hline
\end{tabular}

From the results shown by the table 6 and figure 1, it can be seen that all paths from the dependent variable to the independent variables directly have a significant effect. the path coefficient produced from IT to $\mathrm{M}$ is 0.285 , then from OC to $\mathrm{M}$ is 0.412 , and from $\mathrm{M}$ to $\mathrm{LP}$ is 0.447. Then if you see the effect of the independent variable indirectly on the dependent variable, it can be seen if the P-value is less than 0.05 so that it has a significant effect on the path coefficients from IT and OC to LP through M, respectively 0.127 and 0.184

\section{CONCLUSION}

Based on the result and analysis of research data with a sample of 150 lecturers in Universitas Negeri Semarang, it can be inferred that all independent variables have a significant effect on the dependent variable both directly and indirectly. Information technology variable has a positive effect on the motivation of 0.285. Organizational culture variables has a positive effect on motivation with path coefficient of 0.412. Motivational variables has a positive effect on lecturer performance with path coefficient of 0.447 . Information technology variables indirectly through motivation has a positive effect on lecturer performance with path coefficient of 0.127 . The variable of organizational culture indirectly through motivation has a positive effect on lecturer performance with path coefficient 0.184 .

\section{REFERENCES}

Abbas, J., Muzaffar, A., Mahmood, H. K., Ramzan, M. A., Sibt, S., and Hassan, U. (2014). Impact of Technology on Performance of Employees ( A Case Study on Allied Bank Ltd , Pakistan ) Director NUML , Institute of Business and Finance, Ali Block Garden Town Lahore, Pakistan. World Application of Science Journal, 29 (2), 271-276.

Afful-broni, A. (2012). Relationship between Motivation and Job Performance at the University of Mines and Technology, Tarkwa, Ghana. Leadership Lessons, 3 (3), 309-314.
Angrist, J. D. (2014). Consequences of Employment Protection? The Case of The Americans with Disabilities Act.

Ayu, I., and Suprayetno, A. (2008). Pengaruh Motivasi Kerja , Kepemimpinan dan Budaya Organisasi Terhadap Kepuasan Kerja Karyawan serta Dampaknya pada Kinerja Perusahaan (Studi kasus pada PT. Pei Hai International Wiratama Indonesia). Jurnal Manajemen dan Kewirausahaan, 10 (2), 124-135.

Bhakta, K. (2016). Impact of Information Technology on Teaching-Learning Process. International Research Journal of Interdisciplinary \& Multidisciplinary Studies, 7969 (131), 131-138.

Hussain, S. Bai, S., Rajput, Q., and Khoja, S. A. (2014). Faculty Performance Evaluation System: An ontological approach. Paper presented at AICCSA, 117-124.

Indrajit, R. E. (2007). Manajemen Perguruan Tinggi Modern. Yogyakarta: CV. Andi Offset.

Jahanian, R., Nav, Z. N., and Asadi, A. (2012). The Impact of Information Technology and Communication Training on the Performance of Human Resources in Educational Organizations. World Applied Sciences Journal, 16 (6), 850855.

Karsen, M. (2015). The Role Of Information Technology To Improve Lecturer Performance. Journal of Theoretical and Applied Information Technology, 72 (3), 458-463.

Khaled, K. Z. (2014). The Effect of Information and Communications Technologies ( ICT ) in the Jordanian Universities. Information of Knowledge Management, 4 (12), 122-133.

Kusumajati, D. A. (2017). The Influence of Lecturers' Competencies towards Students' Performance Motivation: A Case Study at Higher Education. Paper presented at International Symposium on Educational Technology, 173-176.

Mangkunegara, A. . A. P. (2012). Evaluasi Kinerja Sumber Daya Manusia. Bandung: PT. Refika Aditama.

Mangkunegara, A. P. (2009). Manajemen sumber daya manusia perusahaan. Bandung: PT Remaja Rosdakarya.

Mathis R. L., and Jacson, J. H. (2000). Human Resource Management, 12th ed. USA: Thomson South-Western.

Narasuci, W., Setiawan, M., and Noermijati. (2018). Effect Of Work Environment On Lecturer Performance Mediated By Work Motivation And Job Satisfaction. Journal of Application Management, 16 (4), 645-653.

Olusadum N. J., and Anulika, N. J. (2018). Impact of Motivation on Employee Performance: A Study of Alvan Ikoku Federal College of Eduaction. Jurnal Managemen Strategi, 9 (1), 53-65. 
Peleyeju J. O., and Ojebiyi O. A. (2013). Lecturers' Performance Appraisal And Total Quality Management Of Public Universities In SouthWestern Nigeria. British Journal of Education, 1 (2), 41-47.

Ramli and Jalinus, N. (2013). Evaluasi Kinerja Guru Sekolah Menengah Kejuruan Sumatera Barat Pascasertifikasi. Jurnal Penelitian dan Evaluasi Pendidikan, 17 (1), 72-87.

Ritawati, A. (2013). Pengaruh Kepemimpinan Transformasional Dan Budaya Organisasi Terhadap Kepuasan Kerja Dan Kinerja Karyawan PT. Jamsostek (Persero) Cabang Surabaya. Jurnal Ilmu Ekonomi Manajemen, 9 (1), 82-93.

Riyadi, H., Utomo, B. S., and Masatip, A. (2017). Pengaruh Komunikasi, Motivasi Kerja Dan Kompetensi Terhadap Kepuasan Kerja Serta Implikasinya Pada Kinerja Dosen Pada Perguruan Tinggi Pariwisata Swasta Di Jawa Barat. 7 (2), 73-90.

Robbins S. P., and Coulter, M. (2012). Management, 11th ed. USA: Pearson Education Limited.

Samuel, L., Kwapong, A., and Opoku, E. (2015). The Effect of Motivation on the Performance of Teaching Staff in Ghanaian Polytechnics: The Moderating Role of Education and Research Experience. Int. J. Educ. Res., 3 (11), 35-48.

Seftiawan, D. (2018). Akhirnya Lampaui Singapura, Publikasi Ilmiah Indonesia ke-2 ASEAN, Pikiran Rakyat.

Sulastri, T. (2007). Hubungan motivasi berprestasi dan disiplin dengan kinerja dosen., J. Optim., 1 (1), 13-21.

Vankatesh, V., Morris, M. G., Davis, G. B., and Davis, F. D., (2003). User Acceptance Of I Nformation Technology: Toward A Unified View. MIS Q., 27 (3), 425-478.

Wigfield, A., Guthrie, J. T., Tonks, S., Perencevich, K. C., Guthrie, J. T., and. Perencevich, K. C. (2014). Children's Motivation for Reading: Domain Specificity, 37-41.

Yahya Z., Hidayati, F. (2014). Analisis Kompetensi Terhadap Penilaian Kinerja Dosen (Studi Kasus Dosen Uin Sultan Syarif Kasim Riau). Jurnal penelitian Sosial dan Keagamaan, 17 (1), 104126. 